\title{
Streamflow and Water Quality in Tarryall Creek Downstream from Park Gulch, Park County, Colorado, April 1997-March 2000
}

\author{
Prepared in cooperation with \\ CITY OF AURORA, COLORADO
}

\section{INTRODUCTION}

Tarryall Creek drains about 450 square miles in Park County, Colorado, and is a tributary of the South Platte River (fig. 1). The City of Aurora, Colorado, has proposed a waterdevelopment project in the Upper Tarryall Creek Basin entitled the South Park Conjunctive Use Project (SPCUP). The project proposes to supply water to the City of Aurora during dry years by pumping ground water from the sedimentary rock South Park Formation into Park Gulch, a tributary of Tarryall Creek. The water would be delivered to Aurora in Colorado's Front Range as streamflow in the South Platte River. During average and wet years, surface water diverted from headwater streams of Tarryall Creek would be used to artificially recharge the aquifer.

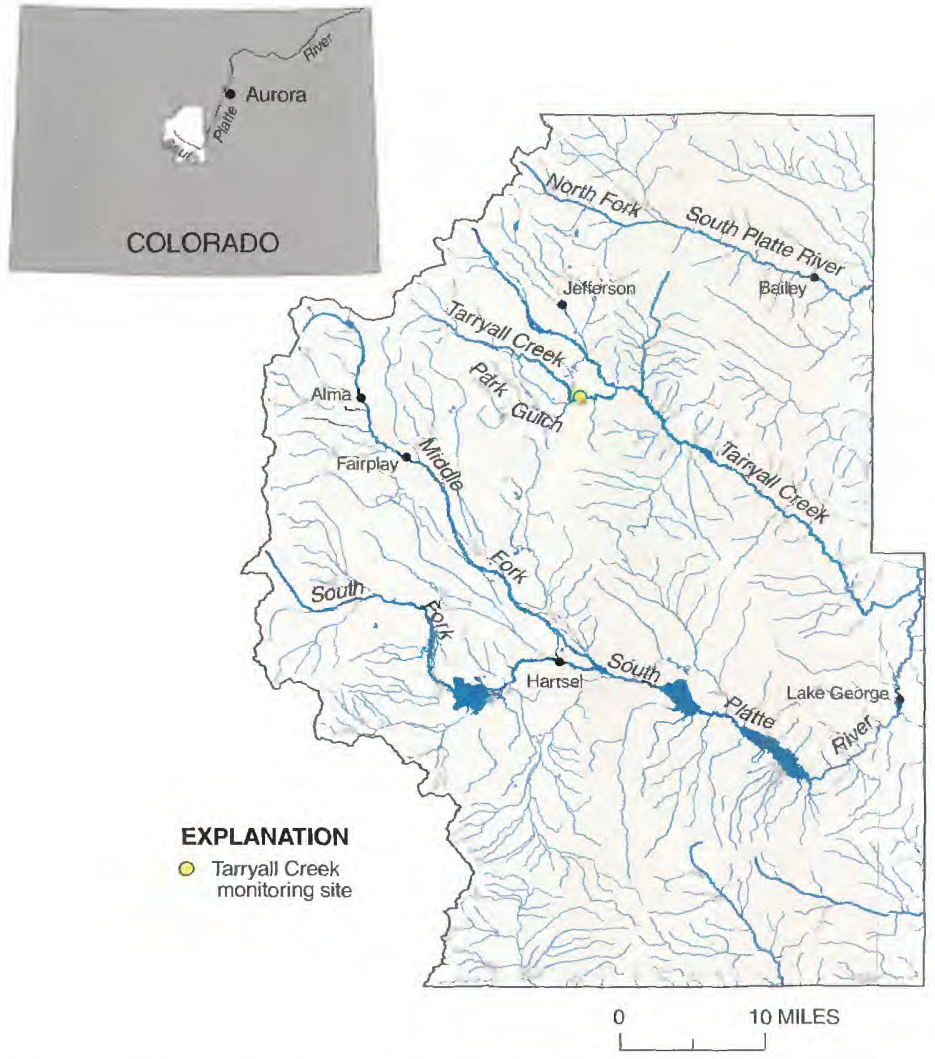

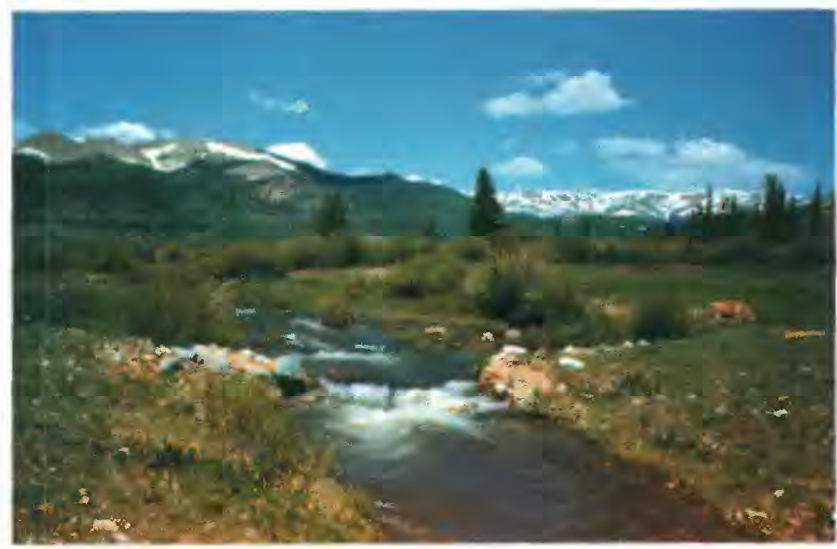

Tarryall Creek about 5 miles upstream from Park Gulch.

Diverting pumped ground water into Tarryall Creek would increase streamflow during certain times of the year and may have the potential to affect instream water quality. Consequently, knowledge of current water-quantity and quality conditions in Tarryall Creek prior to possible implementation of the proposed water-development project is desirable.

In 1997, the U.S. Geological Survey (USGS), in cooperation with the City of Aurora, Colorado, began monitoring streamflow and water quality in Tarryall Creek just downstream from the confluence with Park Gulch (fig. 1). This report presents streamflow and water-quality data that have been collected through March, 2000.

\section{STREAMFLOW}

On May 9, 1997, a continuous-recording streamflow gaging station was installed on Tarryall Creek. The stream gage records stream stage (depth) every 15 minutes and reports the data, via satellite, to the USGS office in Denver. Stream stage is correlated with monthly manual measurements of streamflow to provide a continuous record of the amount of water passing the gage.

Figure 1. Location of Tarryall Creek monitoring site in Park County. 


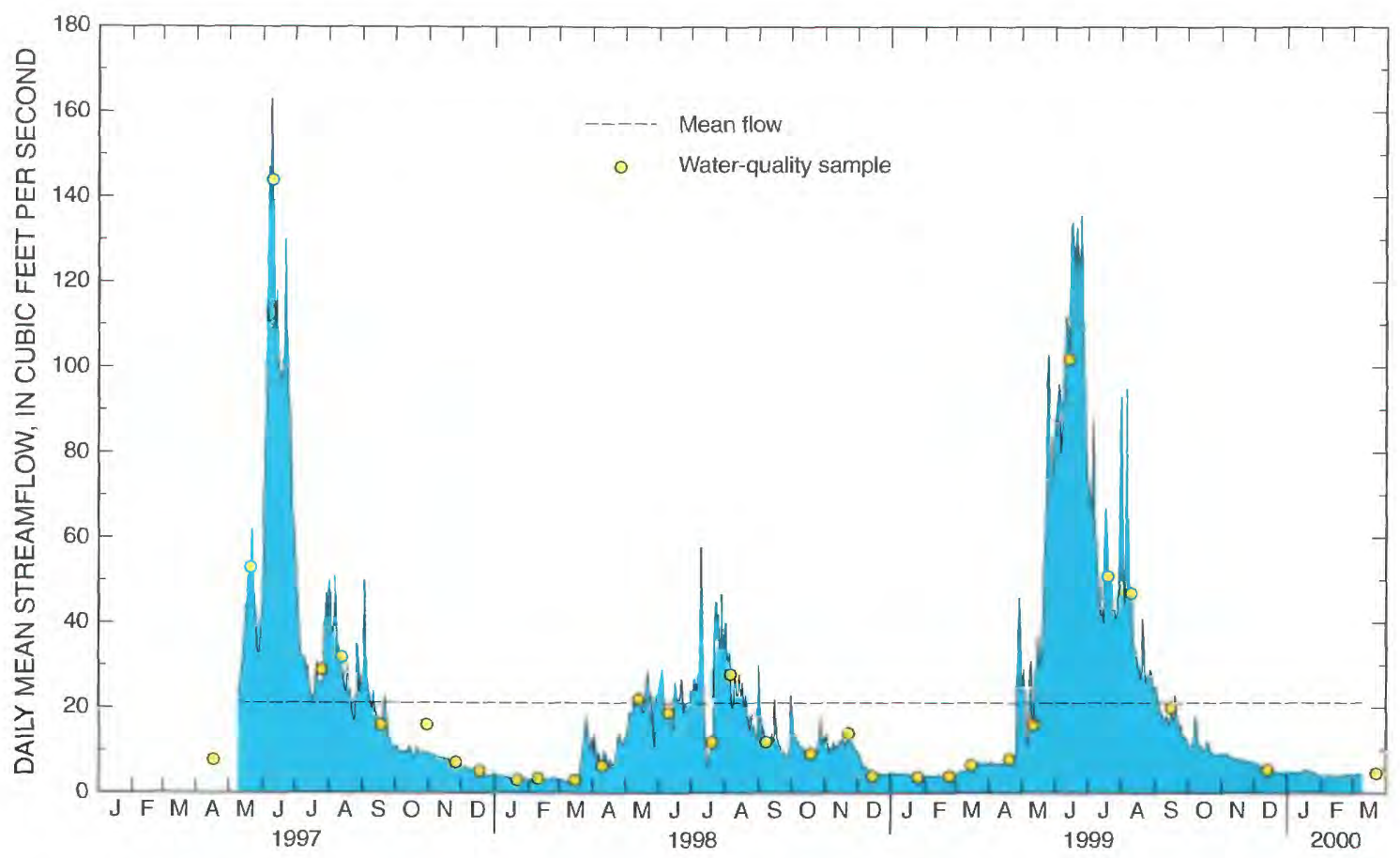

Figure 2. Streamflow hydrograph for Tarryall Creek below Park Gulch, May 9, 1997-March 10, 2000.

Most of the streamflow in Tarryall Creek is derived from melting snow pack in the mountainous parts of the upper watershed. As a result, streamflow is highest from May through August (fig. 2). Streamflow at other times of the year is primarily maintained by ground-water inflow. The hydrograph for Tarryall Creek shows that the magnitude of peak streamflow varies

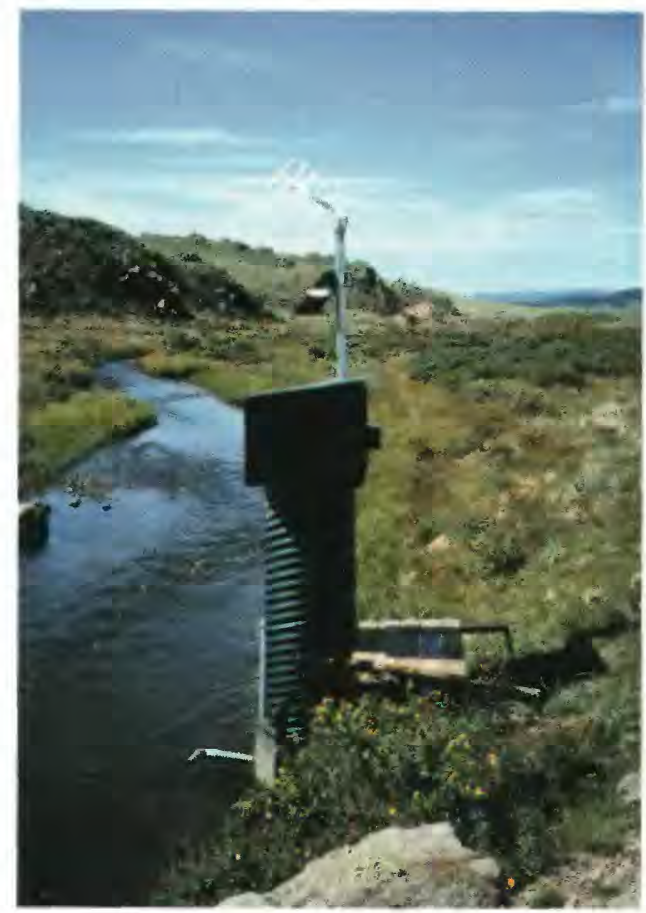

Streamflow gage on Tarryall Creek just downstream from Park Gulch. annually and probably is dependent on the amount of annual snowfall in the basin. Streamflow in 1998 was smaller than streamflow in 1997 and 1999. Increases in streamflow during August through October result from summer rain storms. These peaks in streamflow are large in magnitude but short in duration.

The highest daily mean streamflow recorded for the period of record (May 9, 1997-March 10, 2000) was 163 cubic feet per second $\left(\mathrm{ft}^{3} / \mathrm{s}\right)$ on June 9,1997 . The lowest daily mean streamflow of $2.5 \mathrm{ft}^{3} / \mathrm{s}$ occurred on March 9, 1998. The mean daily flow for the period of record was $21.1 \mathrm{ft}^{3} / \mathrm{s}$.

\section{WATER QUALITY}

The USGS began water-quality monitoring in Tarryall Creek downstream from Park Gulch in April 1997. Water samples were collected monthly through September 1999 and then less frequently through March 2000. Streamflows sampled have ranged from $3 \mathrm{ft}^{3} / \mathrm{s}$ on March 16, 1998, to $144 \mathrm{ft}^{3} / \mathrm{s}$ on June 10 , 1997 (fig. 2). Measurements of water temperature, $\mathrm{pH}$, dissolved oxygen, and specific conductance were obtained onsite, and water samples were collected for analysis of the major dissolved ions, nutrients (compounds of nitrogen and phosphorus), and trace elements (table 1). Water samples were analyzed at the USGS National Water-Quality Laboratory in Lakewood, Colorado.

No values of water temperature, $\mathrm{pH}$, or dissolved oxygen violated instream standards that are applicable to Tarryall Creek (table 1). The standards— set by the Colorado Department of Public Health and Environment (CDPHE) (1999) - are determined on the basis of a streams designated classification with 
Table 1. Selected streamflow and water-quality data for Tarryall Creek downstream from Park Gulch, April $1997-$ March 2000.

$\left[\mathrm{ft}^{3} / \mathrm{s}\right.$, cubic feet per second; ${ }^{\circ} \mathrm{C}$. degrees Celsius; $\mathrm{mS} / \mathrm{cm}$, microsiemens per centimeter; mg/L milligrams per liter: mg/L, micrograms per liter; TVS, Table Value Standard; $\mathrm{pCi} / \mathrm{L}$, picocuries per liter; <, less than detection limit; --, no data or standard]

\begin{tabular}{|c|c|c|c|c|c|}
\hline \multirow{2}{*}{$\begin{array}{l}\text { Constituent or } \\
\text { physical property }\end{array}$} & \multirow{2}{*}{$\begin{array}{c}\text { Number of } \\
\text { detections/samples }\end{array}$} & \multicolumn{4}{|c|}{ Concentration } \\
\hline & & Minimum & Maximum & Median & $\begin{array}{l}\text { Standard or } \\
\text { guideline }\end{array}$ \\
\hline \multicolumn{6}{|c|}{ Field measurements } \\
\hline Discharge $\left(\mathrm{ft}^{3} / \mathrm{s}\right)$ & $32 / 32$ & 3 & 144 & 12 & -- \\
\hline Temperature $\left({ }^{\circ} \mathrm{C}\right)$ & $32 / 32$ & 0 & 18.0 & 4.6 & $1_{20}$ \\
\hline $\mathrm{pH}$ (standard units) & $32 / 32$ & 7.7 & 8.5 & 8.2 & ' $6.5-9.0$ \\
\hline Oxygen, dissolved(mg/L) & $30 / 30$ & 7.1 & 10.6 & 8.8 & ${ }^{1} 6.0$ \\
\hline Specific conductance $(\mu \mathrm{S} / \mathrm{cm})$ & $32 / 32$ & 193 & 379 & 223 & -- \\
\hline \multicolumn{6}{|c|}{ Major ions and solids, dissolved (mg/L) } \\
\hline Bicarbonate & $30 / 30$ & 85 & 144 & 112 & -- \\
\hline Calcium & $32 / 32$ & 27 & 45 & 32 & - \\
\hline Chloride & $32 / 32$ & 0.2 & 2.9 & 0.5 & $1_{250}$ \\
\hline Fluoride & $10 / 32$ & $<0.1$ & 0.2 & $<0.1$ & -- \\
\hline Magnesium & $32 / 32$ & 4.6 & 13 & 5.9 & -- \\
\hline Potassium & $32 / 32$ & 0.4 & 3.9 & 0.9 & - \\
\hline Silica & $32 / 32$ & 2.4 & 11 & 8.4 & - \\
\hline Sodium & $32 / 32$ & 2.5 & 16 & 3.6 & - \\
\hline Sulfate & $32 / 32$ & 9.7 & 72 & 16 & ${ }^{1} 250$ \\
\hline Solids, dissolved & $32 / 32$ & 112 & 258 & 132 & ${ }^{2} 700$ \\
\hline \multicolumn{6}{|c|}{ Nutrients (mg/L) } \\
\hline Nitrogen, ammonia, dissolved & $10 / 32$ & $<0.01$ & 0.13 & $<0.02$ & - \\
\hline Nitrogen, nitrite, dissolved & $2 / 32$ & $<0.01$ & 0.01 & $<0.01$ & ${ }^{1} 0.05$ \\
\hline Nitrogen, nitrite plus nitrate, dissolved & $6 / 32$ & $<0.05$ & 0.25 & $<0.05$ & ${ }^{1} 10$ (nitrate) \\
\hline Nitrogen, ammonia plus organic, total & $25 / 32$ & $<0.1$ & 0.5 & 0.2 & - \\
\hline Nitrogen, ammonia plus organic, & $17 / 32$ & $<0.1$ & 0.5 & 0.1 & - \\
\hline Phosphorus, total & $20 / 32$ & $<0.01$ & 0.09 & 0.02 & ${ }^{3} 0.1$ \\
\hline Phosphorus, dissolved & $9 / 32$ & $<0.01$ & 0.07 & $<0.01$ & - \\
\hline Phosphorus, orthophosphate, dissolved & $12 / 32$ & $<0.01$ & 0.02 & $<0.01$ & ${ }^{3} 0.05$ \\
\hline \multicolumn{6}{|c|}{${ }^{4}$ Trace elements, dissolved ( $\left.\mu \mathrm{g} / \mathrm{L}\right)$} \\
\hline Aluminium & $27 / 32$ & $<1$ & 7 & 2 & -- \\
\hline Arsenic & $2 / 32$ & $<1$ & 2 & $<1$ & ${ }^{1} 50$ (total) \\
\hline Barium & $32 / 32$ & 57 & 90 & 75 & -- \\
\hline Chromium & $15 / 32$ & $<1$ & 3 & $<1$ & ${ }^{1} 11$ \\
\hline Copper & $10 / 32$ & $<1$ & 2 & $<1$ & ${ }^{5} 12.6$ \\
\hline Iron & $31 / 32$ & $<10$ & 170 & 72 & ${ }^{1} 300$ \\
\hline Manganese & $32 / 32$ & 6 & 58 & 10 & ${ }^{1} 50$ \\
\hline Molybdenum & $18 / 32$ & $<1$ & 1 & 1 & - \\
\hline Nickel & $2 / 32$ & $<1$ & 1 & $<1$ & ${ }^{5} 101$ \\
\hline Selenium & $1 / 32$ & $<1$ & 2 & $<1$ & ${ }^{1} 10$ (total) \\
\hline Uranium & $8 / 32$ & $<1$ & 3 & $<1$ & \\
\hline Zinc & $10 / 32$ & $<1$ & 2 & $<1$ & 5113 \\
\hline
\end{tabular}

${ }^{1}$ Standard for Tarryall Creek (Colorado Department of Public Health and Environment, 1999).

${ }^{2}$ Crop losses might occur when dissolved solids of irrigation water exceeds this value (U.S. Department of the Interior, 1994).

${ }^{3}$ For total phosphorus, recommended limit for controlling eutrophication in rivers; for orthophosphate. recommended limit where rivers enter lakes and reservoirs (U.S. Environmental Protection Agency, 1986).

${ }^{4}$ Six of the 18 trace elements analyzed for this study (antimony, beryllium, cadmium, cobalt, lead, and silver) were not detected in any sample above the laboratory reporting limit of 1 microgram per liter and are not listed in table 1 .

${ }^{5}$ Standard for Tarryall Creek calculated with the mean hardness concnetration for this study and the Table Value Standard equations for segment 2a of the South platte River Basin (Colorado Department of Public Health and Environment, 1999). 


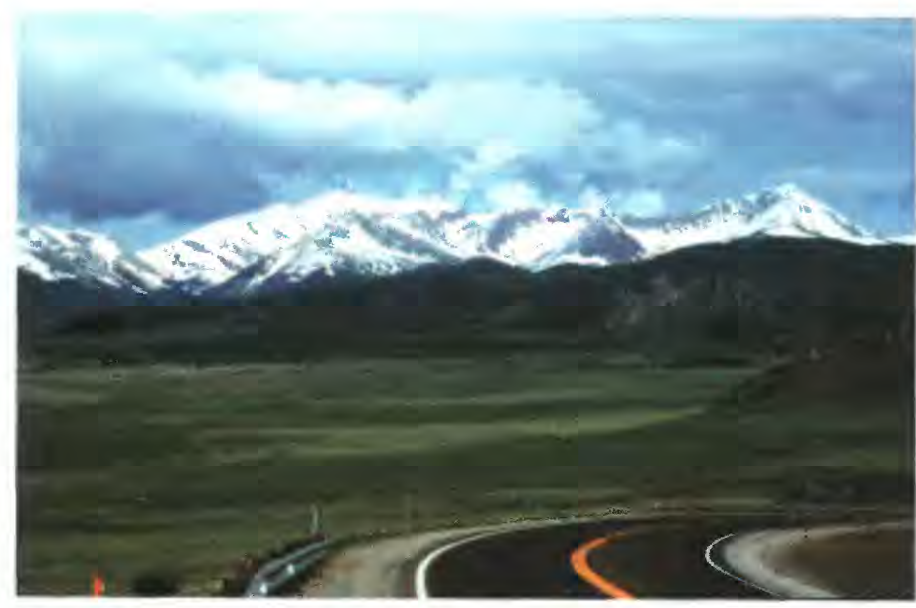

Most of the streamflow in Tarryall Creek is derived from melting snow pack in the mountainous parts of the upper watershed.

regard to aquatic life, recreation, drinking-water supply, and agriculture. The CDPHE has not set standards for specific conductance in Colorado streams.

The major ions analyzed for this study (bicarbonate, calcium, chloride, fluoride, magnesium, potassium, silica, sodium, and sulfate) are constituents commonly dissolved in most natural waters. Concentrations of major ions in solution are influenced primarily by the chemical weathering of rocks but also may be affected by human activity. Median major ion concentrations were highest for bicarbonate and calcium | 112 and 32 milligrams per liter ( $\mathrm{mg} / \mathrm{L}$ ) respectively] and lowest for chloride, fluoride, and potassium (median concentrations less than $1 \mathrm{mg} / \mathrm{L}$ ) (table 1). The CDPHE has set instream standards of $250 \mathrm{mg} / \mathrm{L}$ for two of the major ions - chloride and sulfate. In Tarryall Creek, all concentrations of chloride and sulfate were at least one order of magnitude less than the standards (table 1).

Major ions account for most of the dissolved-constituent concentration in water (also referred to as the dissolved-solids concentration). The CDPHE has not set standards for dissolved solids in Colorado waters; however, crop losses might occur when dissolved-solids concentrations in irrigation water exceed $700 \mathrm{mg} / \mathrm{L}$ (U.S. Department of the Interior, 1994). Dissolved solids in Tarryall Creek ranged from 112 to $258 \mathrm{mg} / \mathrm{L}$ and were well below the irrigation-water guideline (table 1).

Nitrogen and phosphorus are important nutrients for plant growth; however, large nitrogen and phosphorus concentrations in water accelerate the growth of aquatic plants, which in turn leads to degraded aquatic habitat and higher treatment costs for drinking water. Un-ionized ammonia, a form of nitrogen, can be toxic to fish at elevated concentrations. All nitrogen and phosphorus concentrations in Tarryall Creek were less than instream standards or guidelines, including nitrogen in the form of unionized ammonia, nitrite, and nitrate plus nitrite; and phosphorus in the form of dissolved orthophosphate, and total phosphorus (table 1).
The term "trace element" commonly refers to substances that almost always occur in concentrations less than $1 \mathrm{mg} / \mathrm{L}$ in natural waters. Six of the eighteen trace elements analyzed in this study were not detected in any samples, including antimony, beryllium. cadmium, cobalt, lead, and silver. Several other trace elements were detected in less than one-half of the samples, including arsenic, chromium, copper, nickel, selenium, uranium, and zinc (table 1). Some of the more commonly detected trace elements were aluminum, barium, iron, manganese, and molybdenum. The CDPHE has set instream standards for some of the trace elements summarized in table 1 , and with the exception of manganese, all concentrations of these trace elements were less than the standards. Manganese was detected above the 50-micrograms per liter $(\mu \mathrm{g} / \mathrm{L})$ standard in one sample at a concentration of $58 \mu \mathrm{g} / \mathrm{L}$; however, the median manganese concentration was $10 \mu \mathrm{g} / \mathrm{L}$.

Values of water temperature, $\mathrm{pH}$, and dissolved oxygen indicate that water quality is good in Tarryall Creek downstream from Park Gulch. With the exception of manganese in one sample, the concentrations of major ions, nutrients, and trace elements were less than Colorado instream standards and several constituents were not detected in several samples.

\section{REFERENCES}

Colorado Department of Public Health and Environment, 1999, Classifications and numeric standards South Platte River Basin, Laramie River Basin, Republican River Basin, Smoky Hill River Basin: Denver, Water Quality Control Commission, Regulation Number 38, $171 \mathrm{p}$.

U.S. Environmental Protection Agency, 1986, Quality criteria for water, 1986: U.S. Environmental Protection Agency Report 440/5-86-001, [variously paged].

U.S. Department of the Interior, 1994, Salinity update: Denver, Bureau of Reclamation, Colorado River Salinity Program Coordinator, $17 \mathrm{p}$.

\section{-Robert A. Kimbrough}

Technical assistance: Jim A. Collins, and Dennis E. Smits

Editing, Manuscript, and Layout: Carol L Anderson, Joy K. Monson, Sharon P. Clendening

\begin{tabular}{|c|}
\hline For more information contact: \\
Patrick Edelmann, Hydrologic Studies Chief \\
U.S. Geological Survey \\
Norwest Bank Bldg., Suite 200 \\
201 W. 8th Street \\
Pueblo, CO 81003 \\
(719) 544-7155 ext.106 \\
email: pedelman@usgs.gov \\
\hline
\end{tabular}

